\title{
Studi Kemiskinan di Negara Berkembang
}

\author{
Syakieb Sungkar \\ syakieb.sungkar@yahoo.com
}

\begin{abstract}
Abstrak
Penanggulangan kemiskinan di negara berkembang dilakukan dengan berbagai macam cara. Beberapa upaya dari negara diuraikan di sini, seperti memberikan solusi makro dengan meningkatkan pertumbuhan ekonomi nasional, pemberian kemudahan akses kredit perbankan, dan ada juga yang memberikan solusi secara mikro dengan memberikan bantuan langsung tunai (BLT) yang disebut sebagai program pendapatan dasar universal, karena transfer tunai diberikan secara merata ke setiap orang. Diuraikan pula solusi Microfinance seperti yang dilakukan Grameen Bank. Demikian pula pengiriman uang dari buruh migran terhadap keluarganya di tanah air juga dapat mengentaskan kemiskinan. Ada banyak keberhasilan dan tentu saja banyak terdapat kelemahan pada program-program tersebut yang menjadi ruang untuk perbaikan dan peningkatan keberhasilan.
\end{abstract}

Kata Kunci: kemiskinan urban, garis kemiskinan, ketimpangan, hipotetis Kuznets, kredit mikro, pekerja anak, diskriminasi gender, Grameen Bank, bank desa.

Syakieb Sungkar adalah pengamat seni dan lulusan STF Driyarkara.

\section{Pendahuluan - Kemiskinan di Perkotaan Negara Berkembang}

Kemiskinan urban (perkotaan) didefinisikan oleh Sen (1999) yang dikutip dalam UNESC (2007) sebagai hilangnya kemampuan dasar seseorang untuk dapat bebas memilih jalan hidupnya sehingga memiliki alasan untuk dihargai. Kemampuan ini 
termasuk: kesehatan yang baik, pendidikan, jaringan sosial, kontrol atas sumber daya ekonomi, dan pengaruh pada pengambilan keputusan yang mempengaruhi kehidupan seseorang. Di Sudan, misalnya, dimensi agama dan mendengarkan suara para politisi juga termasuk dalam lingkup definisi kemiskinan. Sementara di Malaysia, kemiskinan didefinisikan berdasarkan garis pendapatan yang kira-kira RM510 (170 USD) per bulan untuk keluarga yang terdiri atas 4,6 anggota rumah tangga (Abdul Ghafor et al., 2007). Jumlah itu setara dengan penghasilan 1,23 USD per orang/hari. Sementara definisi miskin menurut Bank Dunia apabila seseorang berpengeluaran kurang dari 1,9 USD per hari. ${ }^{1}$

\begin{tabular}{|c|c|c|}
\hline $\begin{array}{l}\text { Dimension } \\
\text { (Weight) }\end{array}$ & Indicator (Weight) & Poverty Cut-off \\
\hline \multirow{2}{*}{$\begin{array}{l}\text { Health } \\
(1 / 3)\end{array}$} & Nutrition $(1 / 6)$ & $\begin{array}{l}\text { Any adult or child in the household with nutritional } \\
\text { information is undernourished }{ }^{13}\end{array}$ \\
\hline & Child mortality (1/6) & Any child has died in the household ${ }^{14}$ \\
\hline \multirow{2}{*}{$\begin{array}{l}\text { Education } \\
(1 / 3)\end{array}$} & Years of schooling $(1 / 6)$ & No household member has completed five years of schooling \\
\hline & Child school attendance (1/6) & $\begin{array}{l}\text { Any school-aged child in the household is not attending } \\
\text { school up to class } 8^{15}\end{array}$ \\
\hline \multirow{6}{*}{$\begin{array}{l}\text { Standard of } \\
\text { Living }(1 / 3)\end{array}$} & Access to electricity $(1 / 18)$ & The household has no electricity \\
\hline & Access to improved sanitation $(1 / 18)$ & $\begin{array}{l}\text { The household's sanitation facility is not improved or it is } \\
\text { shared with other households }\end{array}$ \\
\hline & Access to safe drinking water $(1 / 18)$ & $\begin{array}{l}\text { The household does not have access to safe drinking water or } \\
\text { safe water is more than } 30 \text { minutes walk round trip }\end{array}$ \\
\hline & Type of flooring material (1/18) & The household has a dirt, sand or dung floor \\
\hline & Type of cooking fuel $(1 / 18)$ & The household cooks with dung, wood or charcoal. \\
\hline & Asset ownership (1/18) & $\begin{array}{l}\text { The household does not own more than one of: radio, TV, } \\
\text { telephone, bike, motorbike or refrigerator, and does not } \\
\text { own a car or truck }\end{array}$ \\
\hline
\end{tabular}

Gambar 1 - Dimensi, Indikator, Pembobotan MPI (OPHI, h. 8).

Sejumlah pembaruan dan analisis inovatif tentang definisi kemiskinan telah diperkenalkan pada tahun 2011 seperti yang dijelaskan dalam Gambar 1. Semenjak tahun 2010, Oxford Poverty and Human Development Initiative (OPHI) bekerja sama dengan United National Development Program (UNDP) memperkenalkan ukuran multidimensi baru dari kemiskinan akut untuk negara berkembang, disebut sebagai Multidimensional Poverty Index (MPI). Indeks Kemiskinan Multidimensi atau MPI adalah rasio Headcount yang disesuaikan dengan menggunakan tiga dimensi

\footnotetext{
${ }^{1}$ Elhadary, Yasin Abdalla Eltayeb (1 Maret 2012). Political Economy and Urban Poverty in the Developing Countries: Lessons Learned from Sudan and Malaysia. Journal of Geography and Geology. Vol. 4, No. 1, www.ccsenet.org/jgg. h. 213.
} 
kesejahteraan, yaitu kesehatan, pendidikan, dan taraf hidup (Alkire dan Santos, 2010). ${ }^{2}$ Tidak ada prosedur tunggal untuk mengukur garis kemiskinan, namun sejumlah parameter harus dipilih untuk memberikan gambaran representatif tentang angka kemiskinan di suatu negara. ${ }^{3}$

Jumlah orang yang tinggal di kota telah meningkat sangat pesat terutama di negaranegara berkembang karena migrasi pedesaan perkotaan besar-besaran serta pertumbuhan penduduk alami. Peningkatan signifikan populasi perkotaan dalam jangka waktu yang singkat telah menimbulkan berbagai masalah antara lain ketimpangan dalam penyediaan layanan sosial, penurunan kegiatan pertanian, dan peningkatan jumlah penduduk miskin perkotaan. Di negara-negara seperti Sudan dan Malaysia, urbanisasi yang cepat dan biaya hidup yang tinggi telah mendorong penduduk perkotaan khususnya kelompok rentan ke dalam kemiskinan yang parah. Meskipun adanya fakta ini, tetapi kurangnya perhatian yang diberikan kepada kaum miskin perkotaan oleh sebagian besar lembaga bantuan internasional dan nasional sehingga mereka hanya berfokus pada kemiskinan di pedesaan. ${ }^{4}$

Populasi perkotaan telah meningkat sangat pesat dan diperkirakan akan terus berlanjut selama beberapa dekade mendatang terutama di negara berkembang. Pada tahun 1950, misalnya, penduduk perkotaan di negara berkembang kurang dari 300 juta dan meningkat menjadi 1,1 miliar pada tahun 1985. Selanjutnya, diproyeksikan bahwa lebih dari 4 miliar orang akan tinggal di perkotaan negara-negara berkembang pada tahun 2025 (UNCHS, 1996). Antara tahun 1990 dan 2000, pertumbuhan penduduk di perkotaan negara maju masing-masing hanya $0,6 \%$ dan $2,9 \%$ per tahun. Namun, di negara berkembang pertumbuhan kota adalah masing-masing 1,8\% dan 3,6\% per tahun (Bank Dunia, 2005). Dalam kecepatan pertumbuhan yang tinggi ini, pengelolaan

\footnotetext{
${ }^{2}$ Alkire, Sabina dan Roche, Jose Manuel (Desember 2011). Sub-national Disparities and Inter-temporal Evolution of Multidimensional Poverty across Developing Countries. Oxford Poverty and Human Development Initiative (OPHI), University of Oxford. h. 8.

${ }^{3}$ Arndt, Channing, Mahrt, Kristi dan Tarp, Finn (2017). Absolute Poverty Lines. Dalam “Measuring Poverty \& Wellbeing in Developing Countries". United Kingdom: Oxford University Press. h. 22.

${ }^{4}$ Elhadary, 212
} 
urbanisasi telah menjadi tantangan utama di antara para perencana dan pengambil keputusan di negara maju dan berkembang (Devas dan Rakodi, 1993; Choguill, 1994). ${ }^{5}$

Meskipun urbanisasi mendorong pembangunan ekonomi, hal itu telah menyebabkan kesenjangan yang lebih lebar antara kota dan antar kelompok sosial yang berbeda karena kota-kota di negara berkembang memiliki sumber daya yang lebih sedikit untuk menanggapi besarnya perubahan tersebut (UNFPA, 2007). Selain itu, proses urbanisasi juga menyebabkan peningkatan yang signifikan dari jumlah penduduk miskin perkotaan. Gambar 2 menunjukkan persentase orang pada tingkat kemiskinan yang berbeda. Angka ini menunjukkan lebih dari 10\% populasi dunia hidup dengan USD 1 per hari. Ironisnya, hanya sekitar 20\% dari populasi dunia hidup di atas USD10,00 per hari. ${ }^{6}$

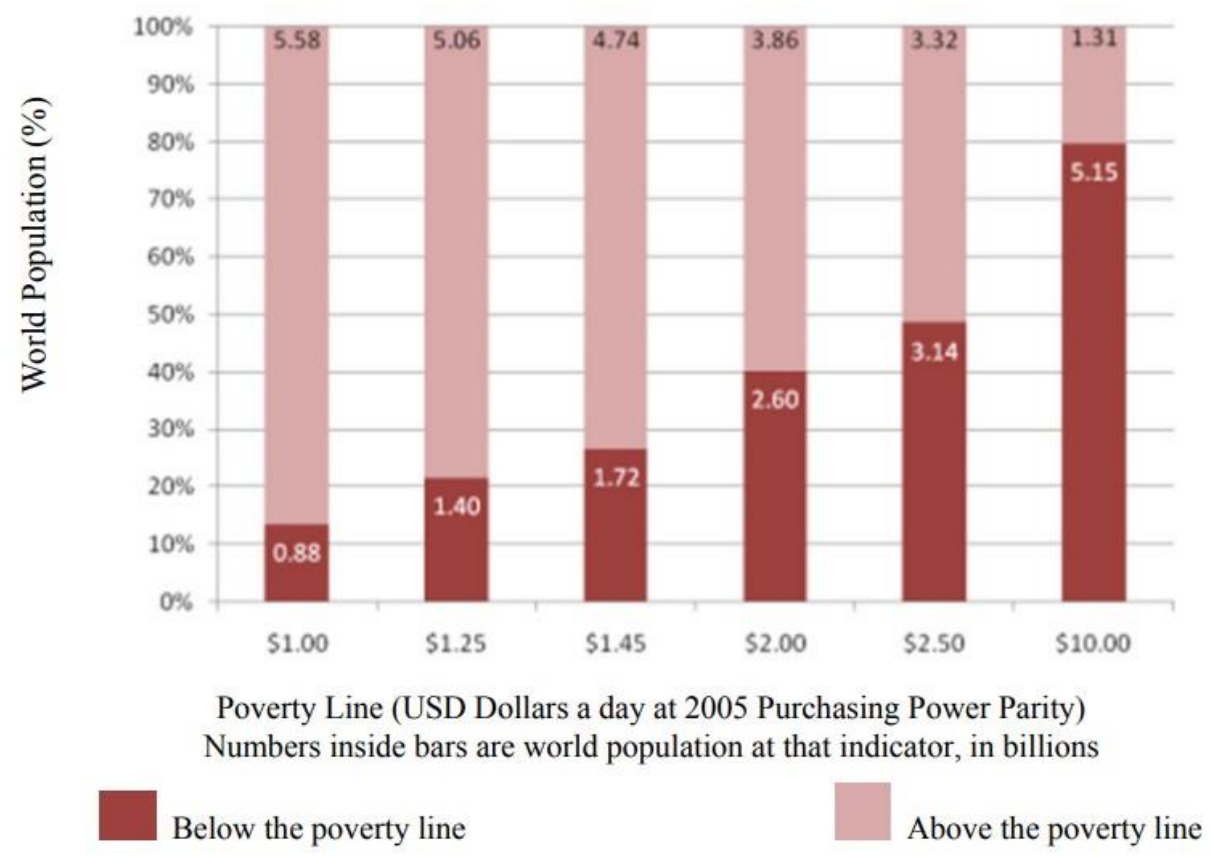

Gambar 2 - Garis kemiskinan dunia, angka dalam bar menunjukan orde miliar orang (Elhadary, h. 223).

\section{Dampak Kemiskinan}

\footnotetext{
${ }^{5}$ Elhadary, 212

${ }^{6}$ Elhadary, 213
} 
Kemiskinan juga mendatangkan dampak ikutan, seperti penggunaan anak-anak dalam pekerjaan di negara berkembang, yang merupakan salah satu masalah utama yang mengganggu masyarakat. Belakangan ini, telah terjadi peningkatan fokus mengenai ancaman pekerja anak secara global. Kemiskinan berhubungan dengan prevalensi pekerja anak, semakin tinggi kemiskinan, semakin banyak anak-anak di pekerjakan di negara-negara berkembang. Menurut Program Internasional tentang Penghapusan Pekerja Anak, diperkirakan 168 juta anak terlibat dalam berbagai kegiatan ekonomi di seluruh dunia, yang menyumbang sekitar $11 \%$ dari seluruh populasi anak-anak secara keseluruhan (IPEC-ILO, 2013). ${ }^{7}$ Seperti dalam grafik pada gambar $3 .{ }^{8}$

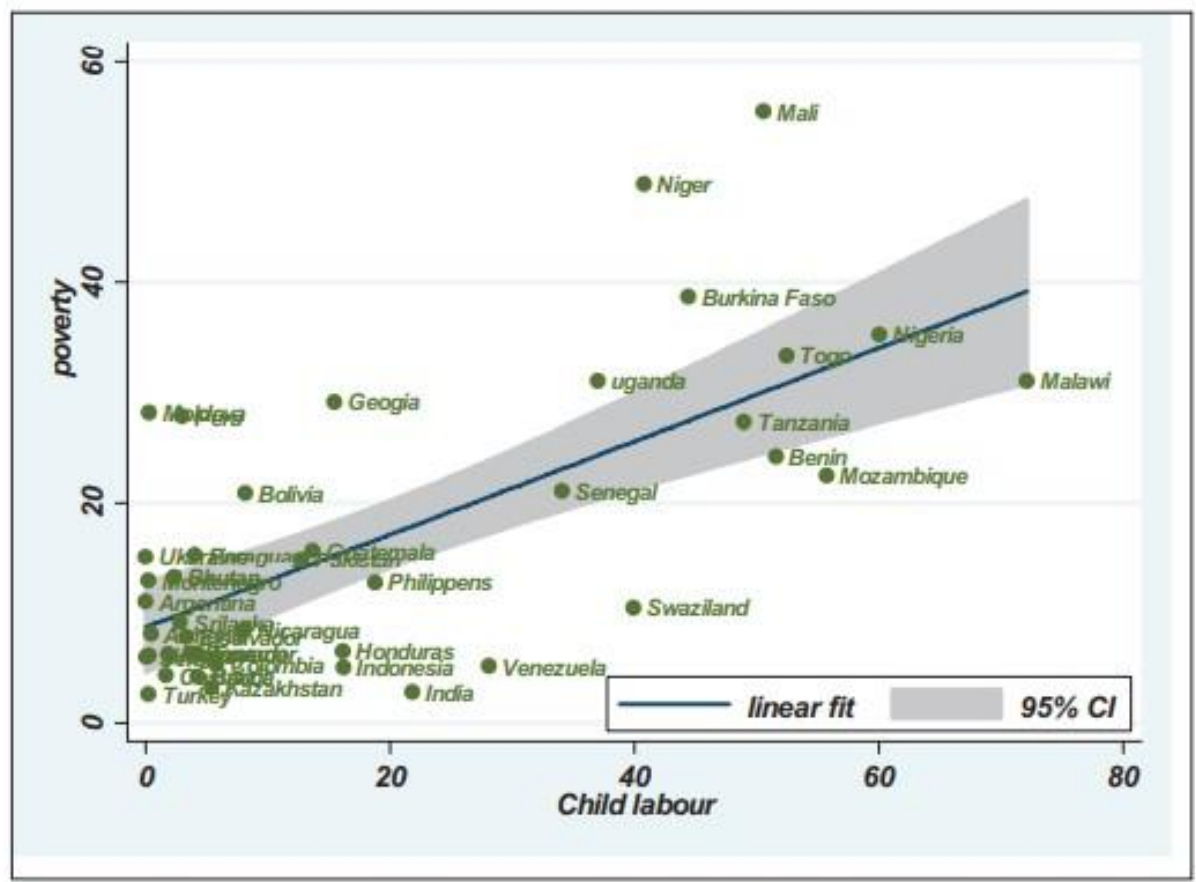

Source: Authors computation based on data from the United State Department of Labor and World Bank's WDI (2014)

Gambar 3 - Pekerja anak dan kemiskinan di 42 negara berkembang pada tahun 20092013

Kemiskinan juga berakibat pada pelecehan seksual terhadap kaum pekerja wanita remaja dan ibu rumah tangga. Pelecehan seksual dan kekerasan seksual terhadap

\footnotetext{
${ }^{7}$ Abdullahi, Idris Isyaku, dkk. (2016). Does Poverty Influence Prevalence of Child Labor in Developing Countries? International Journal of Economics and Financial Issues. Vol. 6, Issue 1, h. 7.

${ }^{8}$ Abdullahi, 8
} 
perempuan di Pakistan, Sri Lanka dan India diperparah karena masyarakat memaafkan dengan alasan perempuan yang dilecehkan berpakaian sedemikian rupa untuk memprovokasi perilaku kekerasan seksual. Mitra \& Kumar (2004) mencatat bahwa sistem hukum di Pakistan, Sri Lanka, dan India telah ada untuk melindungi perempuan, namun pada kenyataannya, perempuan dalam budaya setempat tidak menerima perlindungan yang diinginkan. ${ }^{9}$

Demikian pula ada hubungan antara kemiskinan, pertumbuhan ekonomi, pekerjaan dan rasio ketergantungan usia di negara-negara berkembang. Bahwa rasio ketergantungan usia memiliki dampak yang luar biasa terhadap kemiskinan. Kecukupan terhadap tenaga kerja produktif sangat menentukan pertumbuhan ekonomi. Sementara orang usia tua yang tidak produktif menjadi rentan untuk menjadi miskin. Pertumbuhan ekonomi yang stabil dan peningkatan produktivitas tenaga kerja serta teknologi padat karya merupakan obat mujarab untuk memecahkan masalah kemiskinan. ${ }^{10}$

\section{Upaya Menanggulangi Kemiskinan Melalui Pertumbuhan Ekonomi}

Tujuan utama "Millenium Development Goal" (MDG) adalah proporsi orang miskin yang pendapatannya kurang dari satu dolar per hari akan berkurang setengah dalam kurun waktu tahun 1990 sampai 2015. Salah satu caranya adalah melalui pertumbuhan ekonomi yang dapat mengurangi ketimpangan pendapatan, dengan cara negara berinvestasi di sektor sosial seperti pendidikan dan kesehatan serta meningkatkan kondisi kehidupan penduduk pedesaan. Sejak diterbitkannya laporan tahunan Global Report of Human Development (1990), sebagian besar lembaga bantuan internasional dan donor pembangunan, telah mencadangkan upaya mereka untuk pertumbuhan ekonomi, karena hal itu dipandang sebagai faktor fundamental dalam proses memerangi kemiskinan. Berdasarkan pengeluaran rata-rata yang diperoleh dari survei rumah tangga, Ravallion dan Chen (1996) menyimpulkan jika pertumbuhan ekonomi

\footnotetext{
${ }^{9}$ Dormekpor, Evelyn (2015). Poverty and Gender Inequality in Developing Countries. Developing Country Studies, ISSN 2225-0565, Vol.5, No.10, www.iiste.org, h. 86.

${ }^{10}$ Vijayakumar, Sinnathurai (Juni 2013). An Empirical Study on the Nexus of Poverty, GDP Growth, Dependency Ratio and Employment in Developing Countries. Journal of Competitiveness. Vol 5, Issue 2, h. 72.
} 
meningkat sebesar 1 persen, maka populasi yang hidup dengan pendapatan kurang dari $\$ 1$ per hari, akan berkurang sebesar 3,1 persen. $^{11}$ Hal yang sama juga terjadi Indonesia. $^{12}$

Jika kemiskinan sangat erat kaitannya dengan pertumbuhan ekonomi, maka pertumbuhan berkaitan juga dengan tingkat ketimpangan dan sifat distribusi yang merata atau tidak merata. Walau pertumbuhan ekonomi terjadi tetapi apabila ketimpangan masih besar karena distribusi pendapatan yang tidak merata, maka peran pertumbuhan ekonomi terhadap proses pengentasan kemiskinan menjadi minimal. Landasan teoretis yang menunjukkan hubungan antara pertumbuhan dan ketimpangan adalah hipotesis Kuznets (1955) berdasarkan hubungan lengkung antara pertumbuhan dan ketidaksamaan pendapatan. ${ }^{13}$

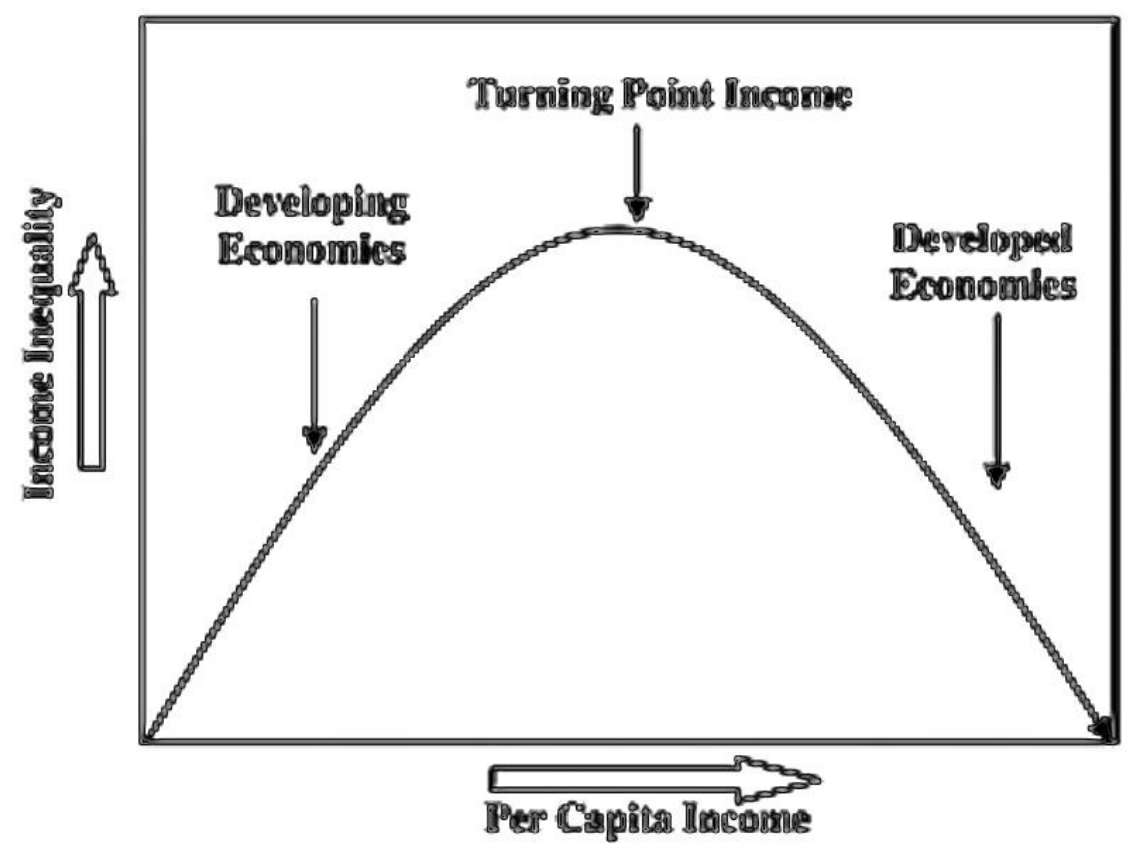

Gambar 4 - Kurva U terbalik Kuznets

\footnotetext{
${ }^{11}$ Guiga, Housseima dan Ben Rejeb, Jaleleddine (2012). Poverty, Growth and Inequality in Developing Countries. International Journal of Economics and Financial, Issues Vol. 2, No. 4, ISSN: 2146-4138, www.econjournals.co, h. 470.

12 Jonaidi, Arius (April 2012). Analisis Pertumbuhan Ekonomi dan Kemiskinan di Indonesia. Jurnal Kajian Ekonomi. Volume 1, Nomor 1, h. 163.

${ }^{13}$ Guiga, 471
} 
Kurva U terbalik ini dapat diuraikan menjadi tiga fase (gambar 4). Pada tahap awal perkembangan, ditandai dengan tingkat pendapatan yang sangat rendah, investasi dalam modal infrastruktur dan modal alam adalah mekanisme utama pertumbuhan, ketimpangan mendorong pertumbuhan dengan berbagi sumber daya bagi mereka yang menabung dan berinvestasi lebih banyak. Selain itu, ketika populasi menjadi urban dan industri tumbuh, ketidaksetaraan meningkat. Dalam tahap perkembangan yang lebih maju, ketika kekayaan terakumulasi, transisi dari investasi fisik menuju investasi dalam teknologi dan sumber daya manusia telah mengurangi ketimpangan. Fase ketiga ditandai dengan tingkat kekayaan yang lebih besar. Peningkatan sumber daya manusia membutuhkan tempat akumulasi modal fisik sebagai sumber utama pertumbuhan. Dengan itu ketimpangan berkurang sementara pertumbuhan terus diwujudkan. ${ }^{14}$ Hasil yang serupa ditemukan pada penelitian Agustin di India dan China dalam kurun 1981 - 2005. ${ }^{15}$ Dan pola yang sama ditemukan pada Pam Zahonogo (2017) di negeri-negeri sub Sahara. ${ }^{16}$

Walau Ucal (2014) menyatakan bahwa pertumbuhan itu berasal dari investasi asing sehingga dapat mengentaskan kemiskinan. ${ }^{17}$ Namun, Imai (2016) menegaskan bahwa pertumbuhan yang dimaksud utamanya dari pertumbuhan pertanian. Di mana pertumbuhan pertanian akan mensimulasi pertumbuhan non-pertanian. Ia menjelaskan apabila pertanian tumbuh maka produk ikutan dan industri yang mensupport pertanian seperti pupuk kimia, peptisida, mesin penggiling padi, akan ikut tumbuh. Demikian pula korelasi antara keberhasilan pertumbuhan di sektor pertanian akan mendorong

\footnotetext{
${ }^{14}$ Guiga, 472

${ }^{15}$ Fosu, Agustin Kwasi (2016). Growth, Inequality, and Poverty Reduction in Developing Countries: Recent Global Evidence. Research in Economic, 71, h. 309-310.

${ }^{16}$ Zahonogo, Pam (2017). Financial Development and Poverty in Developing Countries: Evidence from SubSaharan Africa. International Journal of Economics and Finance; Vol. 9, No. 1.

17 Ucal, Meltem Şengün (2014). Panel Data Analysis of Foreign Direct Investment and Poverty from the Perspective of Developing Countries. Procedia - Social and Behaviour Sciences, h. 1103.
} 
petani untuk memunculkan konsumsi non pertanian. ${ }^{18}$ Hal itu dikonfirmasikan oleh Diaz (2017) dalam penelitiannya di Cape Verde. ${ }^{19}$

Pertumbuhan ekonomi dan penghapusan kemiskinan berkaitan pula dengan sistem finansial yang tersedia. Ada hubungan yang erat antara struktur sistem keuangan dengan pertumbuhan ekonomi, apakah sistem keuangan itu berbasis bank atau sistem keuangan yang berbasis pasar. Dengan mengurangi biaya administrasi dan transaksi, sistem keuangan berbasis bank dapat memberikan dampak besar bagi masyarakat miskin. Kurangnya akses ke sumber finansial menjadi salah satu faktor utama di balik kemiskinan yang permanen (Levine, 2008). Karenanya, di negara berkembang ekspansi bank dan kemudahan akses berkontribusi pada pengurangan kemiskinan, hal ini menyiratkan bahwa lebih banyak sistem keuangan berbasis bank cenderung lebih baik dalam mengangkat orang keluar dari kemiskinan. Tetapi ketika institusi keuangan tumbuh lebih kuat, sistem keuangan berbasis pasar dapat berubah menjadi bermanfaat bagi orang miskin. ${ }^{20}$ Hubungan angka kemiskinan, kualitas lembaga keuangan, sistem finansial berdasarkan pasar dan berdasarkan bank, digambarkan Kpodar seperti pada gambar $5 .^{21}$

Pembangunan sistem finansial dapat membantu masyarakat miskin melalui beberapa jalan. Tingginya biaya unit pinjaman skala kecil membuat orang miskin tidak dapat meminjam untuk investasi. Karenanya, penyediaan layanan keuangan yang lebih baik juga dapat memudahkan pengusaha dan rumah tangga untuk mengelola risiko dan, dengan demikian, memperluas peluang ekonomi mereka (Stiglitz, 1974). Penurunan biaya tetap untuk mengelola risiko dari bank akan menguntungkan rumah tangga miskin secara proporsional. Pembangunan finansial juga meningkatkan kegiatan

\footnotetext{
18 Imai, Katsushi S., dan Cheng, Wenya (18 Agustus 2016). Dynamic and Long Term Linkages among Agricultural and Non-Agricultural Growth, Inequality and Poverty in Developing Countries. Research Institute foe Economics and Bussiness Adminisration, Kobe University. h. 5.

${ }^{19}$ Díaz, Alayde Serruto dan Monagas, Maria del Cristo (13 Oktober 2017). Agricultural Policies and Their Impact on Poverty Reduction in Developing Countries: Lessons Learned from Three Water Basins in Cape Verde Serafin Corral. Sustainability 2017, 9, 1841; doi:10.3390/su9101841, www.mdpi.com/journal/sustainability.

${ }^{20}$ Kpodar, Kangni dan Singh, Raju Jan (Desember 2011). Does Financial Structure Matter for Poverty? Evidence from Developing Countries. The World Bank, Poverty Reduction and Economic Management Unit. h. 2

${ }^{21}$ Kpodar, 13
} 
ekonomi sehingga dapat meningkatkan permintaan tenaga kerja. Jika peningkatan permintaan tenaga kerja ini ditujukan pada pekerja berketerampilan rendah, efek tidak langsung dari pembangunan keuangan dapat meningkatkan pendapatan masyarakat miskin dan mengurangi ketimpangan pendapatan. ${ }^{22}$ Hal yang saat ini sedang diusahakan di Nigeria. ${ }^{23}$ Melampaui persoalan ekonomi, memang salah satu biang keladi kemiskinan secara umum adalah ekslusi sosial. Hal yang sedang diusahakan di India. ${ }^{24}$ Penelitian Wieser (2011) menyimpulkan, kebijakan tentatif untuk negara berkembang yang mencoba mengurangi kemiskinan adalah, pertama-tama fokus pada pertumbuhan tetapi kedua untuk melengkapi strategi ini adalah dengan kebijakan yang ditujukan untuk meningkatkan sumber daya manusia dan keterbukaan politik. ${ }^{25}$

Demikian pula, pengembangan finansial dapat meningkatkan persaingan di sektor nonkeuangan dengan memperlancar ijin usaha dan masuknya perusahaan baru. Menurut Becker (1957), hal ini menimbulkan persaingan, mengurangi diskriminasi dalam merekrut pekerja dan memperluas kesempatan ekonomi kelompok yang kurang beruntung, yaitu masyarakat miskin. Banyak penelitian yang menemukan bukti korelasi positif antara akses keuangan dan kemiskinan. Jacoby (1994), misalnya, menemukan bahwa kurangnya akses kredit melanggengkan kemiskinan di Peru karena rumah tangga miskin tidak mampu menyediakan pendidikan yang sesuai untuk anaknya. Jacoby dan Skoufias (1997) menunjukkan bahwa rumah tangga dari desa-desa di India tanpa akses ke pasar kredit cenderung mengurangi sekolah anak-anak mereka karena kekurangan biaya. Demikian pula, Dehejia dan Gatti (2003) dan Beegle dkk. (2003) menunjukkan bahwa tingkat pekerja anak lebih tinggi di negara-negara yang mempunyai sistem keuangan yang buruk. ${ }^{26}$

\footnotetext{
22 Kpodar, 3

${ }^{23}$ Olajide, Fadun S. (May 2014). Financial Inclusion, Tool for Poverty Alleviation and Income Redistribution in Developing Countries: Evidences from Nigeria. Academic Research International, Vol. 5(3), h. 143.

${ }^{24}$ de Haan, Arjan dan Maxwell, Simon (October 2017). Poverty and Social Exclusion in North and South. IDS Bulletin, Vol. 48 No. 1A. h. 3-4.

25 Wieser, Christina (November 2011). Determinants of the Growth Elasticity of Poverty Reduction: Why the Impact on Poverty Reduction is Large in Some Developing Countries and Small in Others. WIFO dan WU-Wien, Econstor, www.econstor.eu., h. 38.

${ }^{26}$ Kpodar, 3
} 


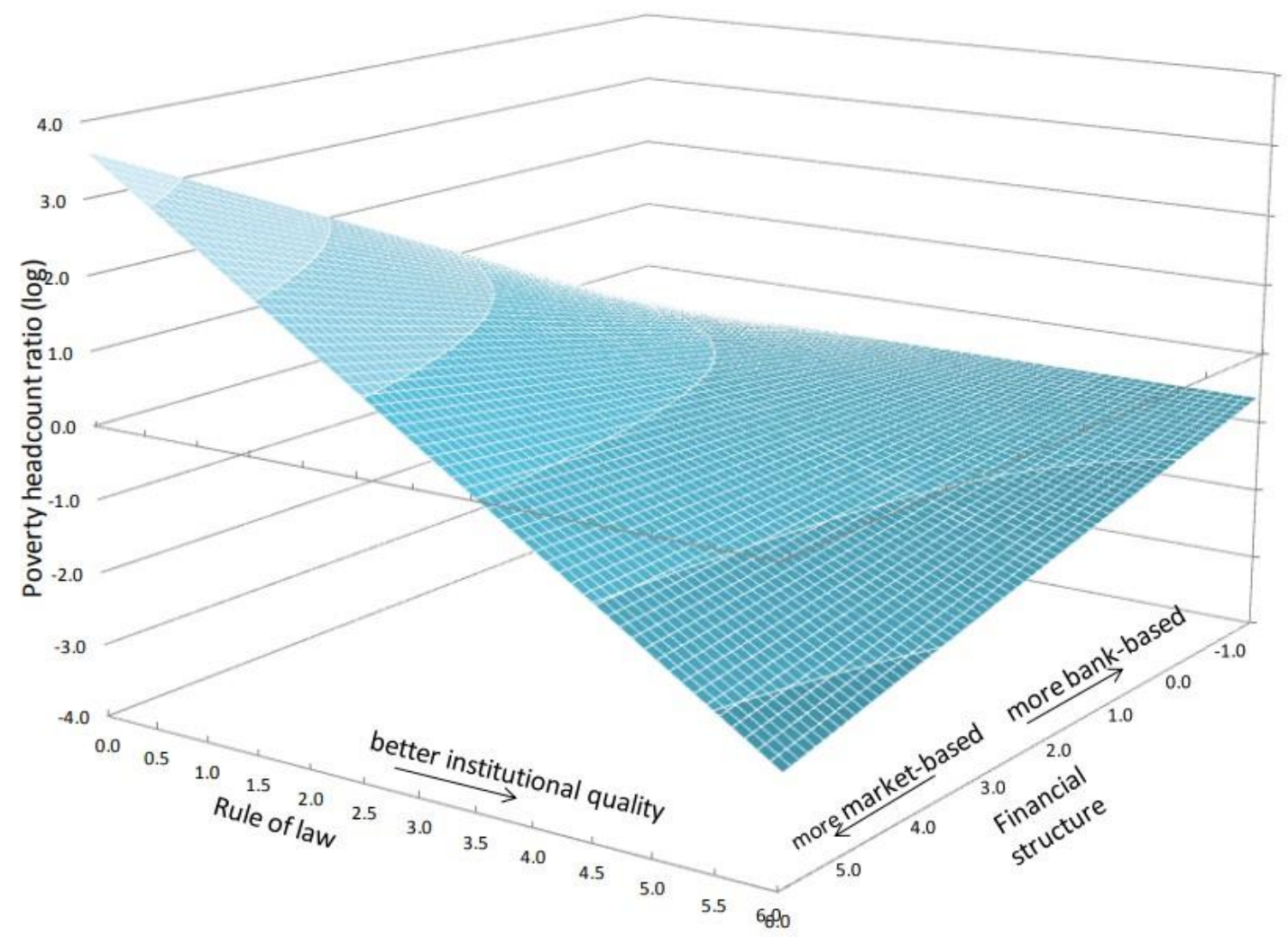

Gambar 5 - Hubungan angka kemiskinan, kualitas lembaga keuangan, sistem finansial berdasarkan pasar dan berdasarkan bank (Kpodar, h. 13).

\section{Program Anti-Kemiskinan Berupa Bantuan Transfer Tunai (BLT)}

Selain solusi makro yang berupa pertumbuhan ekonomi, menghilangkan ketimpangan, dan akses kredit perbankan, ada juga program transfer tingkat nasional untuk membantu keluarga miskin. Program semacam itu sering dijalankan oleh pemerintah negara berkembang. Misalnya di pedesaan China, ada program yang menjamin masyarakat memenuhi standar hidup minimum (Dibao) yang mencakup 75 juta individu (Golan, Sicular, dan Umapathi 2017). Sementara di Mexico ada program uang tunai bersyarat yang transfernya mencapai 32 juta orang (Bank Dunia 2014). ${ }^{27}$

\footnotetext{
${ }^{27}$ Hanna, Rema dan Olken, Benjamin A. (2018). Universal Basic Incomes versus Targeted Transfers: AntiPoverty Programs in Developing Countries. Journal of Economic Perspectives, Volume 32 No. 4. h. 201.
} 
Banyak negara yang telah menerapkan program transfer, berusaha untuk menargetkan penerima manfaat: yaitu, untuk mengidentifikasi siapa yang miskin dan kemudian mentransfer kepada mereka per individu. Di negara berkembang, pemerintah tidak mempunyai data jumlah pendapatan sebagian besar mayoritas penduduk yang bekerja di sektor informal, yang biasanya terdiri atas orang miskin. Sehingga seringkali memberikan transfer kepada mereka yang tidak miskin, atau gagal mengirimkan transfer ke individu miskin yang berhak. ${ }^{28}$

Mengingat adanya masalah ini, beberapa negara telah memulai program "pendapatan dasar universal", yang menghilangkan upaya untuk mengidentifikasi orang miskin dan sebagai gantinya memberikan transfer kepada semua orang. Program "pendapatan dasar universal" relatif mudah untuk diterapkan — setiap individu menerima transfer tetap, namun tantangan utamanya adalah memastikan bahwa setiap orang menerima sekali transfer saja. Penelitian Hanna \& Olken (2018) memeriksa bagaimana penargetan transfer dilakukan dalam pengaturan program ini, di Indonesia dan Peru—dua negara yang menjalankan program transfer nasional yang menyasar masyarakat miskin.

Pendapatan dasar universal biasanya dipahami sebagai transfer tetap yang diberikan kepada semua orang, tanpa memandang tingkat pendapatan. Program semacam itu cukup jarang dalam praktiknya, dengan contoh menonjol datang dari tempat-tempat dengan pendapatan sumber daya alam yang besar. Misalnya, Dana Permanen Alaska mentransfer sejumlah uang — biasanya antara $\$ 1.000$ dan $\$ 2.000$ per orang, per tahun — untuk setiap warga negara bagian. Iran menerapkan program serupa mulai tahun 2011 (Salehi-Isfahani dan Mostafavi-Dehzooei 2017). Argumen umum yang dibuat untuk program pendapatan dasar universal antara lain kemudahan pelaksanaan dan biaya administrasi yang rendah, karena pemerintah tidak perlu memverifikasi pendapatan. Klaim umum lainnya adalah bahwa program tidak mendistorsi pasokan tenaga kerja, karena pembayaran tidak menurun jika penerima BLT bekerja lebih banyak. ${ }^{29}$

\footnotetext{
${ }^{28}$ Hanna, 202

${ }^{29}$ Hanna, 203
} 


\section{Program Microfinance}

Keuangan mikro merupakan penyediaan jasa keuangan untuk masyarakat berpenghasilan rendah (UNDP Microstart Guide1997). Layanan keuangan menurut Ledgerwood (1999), umumnya mencakup tabungan dan kredit, asuransi dan pembayaran jasa. Schreiner dan Colombet (2001, h.339) mendefinisikan keuangan mikro sebagai "upaya untuk meningkatkan akses ke simpanan dan pinjaman kecil untuk rumah tangga miskin yang diabaikan oleh bank." Karena itu, keuangan mikro melibatkan penyediaan layanan keuangan untuk orang miskin yang tinggal di perkotaan dan pedesaan yang tidak mampu untuk memperoleh layanan tersebut dari sektor keuangan formal, menyediakan keluarga yang sangat miskin dengan pinjaman yang sangat kecil (kredit mikro) untuk membantu mereka terlibat dalam kegiatan produktif atau mengembangkan usaha kecil mereka. Seiring waktu, keuangan mikro telah mencakup layanan yang lebih luas (kredit, tabungan, asuransi dll.) seperti yang telah kita sadari bahwa orang miskin dan orang yang sangat miskin yang kekurangan akses ke lembaga keuangan formal tradisional memerlukan berbagai produk keuangan (www.cgap.org,). ${ }^{30}$

Bank Dunia mendefinisikan keuangan mikro sebagai "keuangan skala kecil" layanan terutama kredit dan tabungan yang diberikan kepada orang-orang yang bertani, memancing, penggembala ternak, orang-orang yang mengoperasikan usaha kecil atau usaha mikro di mana barang diproduksi, didaur ulang, diperbaiki, dan dijual, orangorang yang pendapatannya dari menyewakan sejumlah kecil tanah, kendaraan, dan hewan penarik (The World Bank - Perspectives on Development - Winter 2001/2002, h. 90).

Keuangan mikro telah terbukti menjadi salah satu alat yang efektif untuk pengurangan kemiskinan di negara berkembang. Mengikuti kisah sukses Bank Grameen di Bangladesh, revolusi keuangan mikro telah menyerbu negara-negara berkembang saat

\footnotetext{
${ }^{30}$ Addae-Korankye, Alex (Oktober 2012). Microfinance: a tool for poverty reduction in developing countries. Journal of Bussiness and Retail Management Research (JBRMR). Vol 7, Issue 1, h. 140
} 
ini. Namun sistem ini harus diterapkan dan dikelola dengan hati-hati, ketika layanan dirancang untuk memenuhi kebutuhan klien, keuangan mikro memiliki dampak positif, tidak hanya pada klien, tetapi juga pada keluarga mereka dan pada masyarakat luas. Direkomendasikan antara lain bahwa perlu lebih banyak upaya diarahkan ke institusi pembinaan termasuk penguatan kelompok swadaya masyarakat (LSM). Perlu juga pengembangan sistem informasi manajemen yang lebih efektif untuk mendorong konsolidasi pemberian layanan keuangan yang berkelanjutan melalui LSM yang berperformansi baik. ${ }^{31}$

Model Keuangan Mikro di negara berkembang diantaranya adalah model Grameen, Solidarity Group, Bank Desa dan banyak lainnya. Model Grameen menargetkan klien dari daerah pedesaan atau perkotaan (padat penduduk) dan biasanya (walaupun tidak eksklusif) perempuan dari kelompok berpenghasilan rendah. Pemilihan klien dilakukan melalui tes yang diterapkan untuk memastikan penjangkauan kepada orang-orang yang sangat miskin yang mengejar kegiatan-kegiatan yang menghasilkan pendapatan-usaha mikro (Ledgewood, 1997). Pinjaman diberikan kepada individu dalam kelompok yang terdiri dari empat sampai tujuh anggota yang secara kolektif menjamin pembayaran pinjaman, dan akses ke pinjaman berikutnya adalah tergantung pada keberhasilan pembayaran oleh semua anggota kelompok. Pembayaran biasanya dilakukan mingguan (Berenbach dan Guzman, 1994). ${ }^{32}$

Bank Desa adalah asosiasi simpan pinjam yang dikelola masyarakat didirikan untuk menyediakan akses ke layanan keuangan di daerah pedesaan, membangun kelompok swadaya masyarakat, dan membantu anggota mengumpulkan tabungan (Otero dan Rhyne, 1994). Model ini dikembangkan pada pertengahan 1980-an oleh Foundation for International Community Assistance (FINCA). Keanggotaan di bank desa biasanya berkisar antara 30 sampai 50 orang, yang sebagian besar adalah wanita. Bank dibiayai dengan mobilisasi internal dana anggota serta pinjaman yang diberikan oleh Lembaga Keuangan Mikro (LKM).

\footnotetext{
${ }^{31}$ Addae-Korankye, 139

${ }^{32}$ Addae-Korankye, 142
} 
Kelompok Solidaritas memberikan pinjaman kepada anggota individu dalam kelompok empat sampai tujuh. Para anggota saling menjamin pinjaman satu sama lain untuk menggantikan agunan tradisional. Klien umumnya adalah pedagang pasar wanita yang menerima pinjaman modal kerja kecil jangka pendek. Model ini dikembangkan oleh ACCION Internasional di Amerika Latin dan telah diadaptasi oleh banyak LKM.

Menurut Morduch dan Haley (2001), ada banyak bukti bahwa keuangan mikro memiliki dampak positif: bahwa jumlah orang yang hidup dalam kemiskinan ekstrim (didefinisikan sebagai mereka yang hidup dengan kurang dari \$1 per hari) akan berkurang setengahnya antara tahun 1990 dan 2015. Hossain (1988) menegaskan bahwa "Anggota Grameen Bank memiliki pendapatan sekitar 43\% lebih tinggi dari kelompok di desa sasaran”. Sebuah studi yang dilakukan oleh Bank Dunia bekerja sama dengan Institut Studi Pembangunan Bangladesh, dan dikutip oleh Hashemi dan Morshed (1997), menunjukkan bahwa Grameen Bank tidak hanya "mengurangi kemiskinan dan meningkatkan kesejahteraan peserta" rumah tangga tetapi juga meningkatkan kapasitas rumah tangga dari waktu ke waktu.” Selanjutnya Kamal (1996) "mencatat tingkat pendapatan per kapita yang lebih tinggi di kalangan mikro" dibandingkan dengan mereka yang tidak meminjam. Penelitian yang dilakukan oleh Chowdhury dkk. (1991), menunjukkan orang yang berpartisipasi memiliki lebih banyak pendapatan dan aset daripada bukan peserta”. Mustofa dkk. (1996) mengkonfirmasi ini dan mencatat bahwa "anggota memiliki kapasitas mengatasi keuangan yang lebih baik di musim paceklik yang meningkat dengan lamanya keanggotaan dan jumlah kredit yang diterima. Menurut penelitian, mereka yang telah menjadi anggota program Keuangan Mikro selama 48 bulan atau lebih mengalami peningkatan aset sebesar $112 \% .^{33}$

\section{Pengentasan Kemiskinan Melalui Pengiriman Uang Buruh Migran}

\footnotetext{
${ }^{33}$ Addae-Korankye, 145
} 
Pengiriman uang (remittance) kepada keluarga di tanah air dari pekerja migran di luar negeri juga diidentifikasi sebagai upaya pengentasan kemiskinan. Ketika kita mempertimbangkan hubungan antara migrasi dan pembangunan, remitansi internasional dianggap sebagai salah satu elemen terpenting yang berkontribusi pada perkembangan negara pengirim tenaga kerja. Pengiriman uang internasional mengacu pada uang dan barang yang dikirim ke rumah tangga oleh pekerja migran yang bekerja di luar negara asalnya negara (Adams 2007).

Pengiriman uang internasional merupakan sumber pendanaan eksternal terpenting kedua untuk negara berkembang setelah penanaman modal asing langsung (FDI). Peningkatan $1 \%$ dalam pengiriman uang internasional sebagai persentase dari PDB dapat menyebabkan penurunan rasio kesenjangan kemiskinan sebesar 22,6\% dan penurunan kemiskinan parah sebesar 16,0\%. Hal itu didapat berdasarkan penelitian Naoyuki Yoshino dkk. terhadap 10 negara berkembang di Asia dalam kurun waktu 1981-2014. ${ }^{34}$ Hafiz Muhammad Abubakar Siddique (2016) dalam penelitiannya mendapatkan kontribusi remitansi luar negeri dalam total pendapatan negeri-negeri Asia Selatan menunjukkan proporsi yang signifikan, yaitu 4,2\% dari PDB dan memiliki dampak yang besar terhadap pengentasan kemiskinan. ${ }^{35}$ Serinoa dan Kim mencatat penurunan kemiskinan dari $23.2 \%$ di 1981 menjadi $18.83 \%$ di 2005 pada negara-negara Asia Selatan. ${ }^{36}$

\section{Tanggapan Atas Model-model Penanganan Kemiskinan}

Kemiskinan masih terus menjadi momok pada negara berkembang. Diperkirakan ada peningkatan kemiskinan yang cukup besar-naik hingga 400 juta orang miskin baru

\footnotetext{
34 Yoshino, Naoyuki, Taghizadeh-Hesary, Farhad, dan Otsuka, Miyu (2017). International Remittances and Poverty Reduction: Evidence from Asian Developing Countries. ADB Institute.

35 Siddique, Hafiz Muhammad Abubakar, dkk. (2016). Do International Migration and Remittances Reduce Poverty in Developing Countries? MPRA, Maret-April. h. 1522.

${ }^{36}$ Serinoa, Moises Neil V. dan Kim Donghun (December 2011). How Do International Remittances Affect Poverty in Developing Countries? a Quantile Regression Analysis. Journal of Economic Development, Volume 36, No. 4.
} 
yang hidup di bawah garis kemiskinan \$1,90 sebagai dampak dari pandemi COVID19. Andy Sumner, Eduardo Ortiz-Juarez, Chris Hoy (Juni 2020) membuat kurva perkiraan peningkatan kemiskinan (gambar 6). Di mana garis putus-putus setelah 2018 mewakili perkiraan peningkatan kemiskinan, dengan garis putus-putus bawah, tengah, dan atas mewakili, masing-masing, 5, 10, dan 20 persen kontraksi. ${ }^{37}$
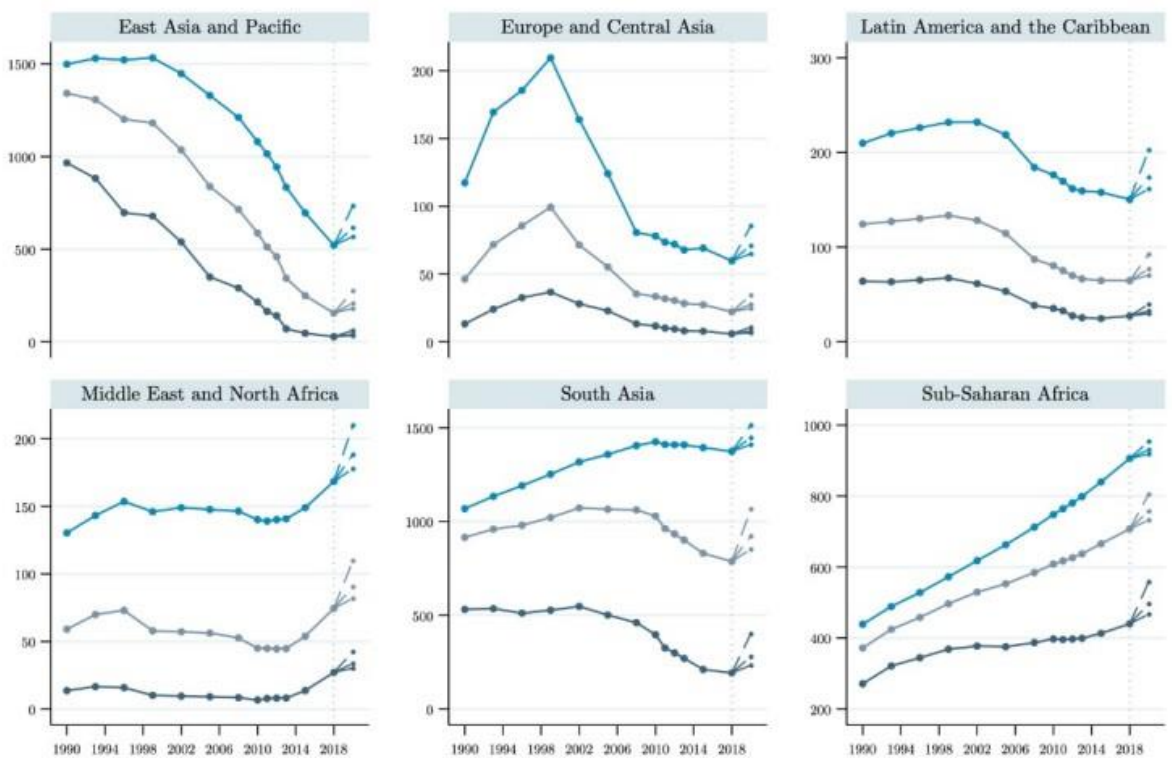

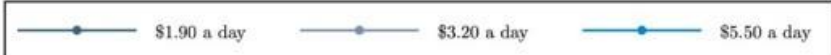

Gambar 6 - Perkiraan peningkatan kemiskinan karena Covid-19.

Kebijakan social distancing untuk memerangi pandemi COVID-19 sulit dicapai di negara-negara berpenghasilan rendah, karena sebagian besar populasi dipaksa untuk melanjutkan kegiatan yang menghasilkan pendapatan untuk keluar dari kemiskinan atau kelaparan yang ekstrem. Dapat dibayangkan bagaimana tingkat kemiskinan yang lebih tinggi diterjemahkan menjadi penyebaran kasus COVID-19 yang lebih cepat melalui saluran mobilitas kerja. ${ }^{38}$

\footnotetext{
37 Sumner, Andy dan Ortiz-Juarez, Eduardo dan Hoy, Chris (Juni 2020). Precarity and the Pandemic: COVID-19 and Poverty Incidence, Intensity, and Severity in Developing Countries. UNU-WIDER, Econstor, www.econstor.eu., h. 12.

${ }^{38}$ Bargain, Olivier dan Aminjonov, Ulugbek (Mei 2020). Between a Rock and a Hard Place: Poverty and COVID19 in Developing Countries. IZA - Institute of Labour Economy. www.iza-org. h. 12-14.
} 
Demikian pula dengan kebijakan emisi karbon untuk mitigasi perubahan iklim global, perlu dipertimbangkan dampaknya terhadap penambahan angka kemiskinan di negara berkembang. Pembatasan pembalakan liar dan penjagaan lahan untuk daerah hijau, mungkin sekali akan membatasi akses petani untuk menambah pendapatan. Walau di sisi lain ada kesempatan untuk menjual produk hijau yang harganya lebih mahal. Hal tersebut perlu ditelaah lebih mendalam, terutama untuk Indonesia yang hutannya perlu dipertahankan demi menjaga pemanasan global. $^{39}$

Terlihat banyak alternatif yang diberikan di negara berkembang untuk mengentaskan kemiskinan, namun perlu dicari solusi yang cocok untuk kondisi Indonesia. Bahwa pertumbuhan ekonomi makro akan menurunkan angka kemiskinan secara keseluruhan perlu disikapi dengan kritis, karena untuk kasus Indonesia - angka GINI masih besar, artinya jurang pemisah antara yang kaya dan miskin belum banyak tertutupi. Demikian pula untuk pembukaan akses bank ke pelosok-pelosok, saat ini baru BRI saja yang berani investasi masuk ke daerah tertinggal, sementara bank swasta masih enggan untuk melebarkan sayap ke daerah terpencil dengan pertimbangan biaya yang tinggi padahal revenue yang masuk terlalu kecil. Namun di sisi lain, pelayanan BRI masih tertinggal terutama untuk pelayanan yang bersifat IT based, terasakan dari banyaknya jaringan ATM yang mati. Dapat dibayangkan apabila hal itu terjadi di daerah terpencil yang jangkauan internetnya masih terbatas.

Solusi pertumbuhan ekonomi yang didasarkan pada berkembangnya sektor pertanian juga harus disesuaikan dengan kondisi Indonesia, mengingat banyak petani di desa sebenarnya hanya sebagai petani penggarap saja. Artinya jika pertanian tumbuh, yang merasakan dampaknya justru para pemilik lahan. Pengentasan kemiskinan melalui pengembangan pertanian, barangkali perlu diiringi dengan kebijakan redistribusi lahan, agar petani kembali memiliki tanah garapan. Namun kebijakan ini sangat berimpitan dengan strategi mitigasi iklim global di mana kelestarian hutan harus dijaga.

\footnotetext{
${ }^{39}$ Husein, Zekarias, Hertel, Thomas dan Golub, Alla (2013). Climate Change Mitigation Policies and Poverty in Developing Countries. Environmental Research Letters. Volume 8. IOP Publishing.
} 
Penyaluran BLT, di mana Indonesia sangat berpengalaman dalam hal ini, terutama di masa pandemi 2 tahun belakangan, sangatlah rawan dengan duplikasi data penerima. Di samping kaum urban perkotaan belum memiliki KTP di kota yang ia huni, sehingga orang-orang yang berhak menerima tunjangan justru tidak kebagian. Hal lain adalah korupsi terhadap BLT yang terjadi di segala lapisan, dari Pusat sampai daerah, sehingga jumlah BLT yang didapat hanya berkisar pada angka 50\% saja. BLT akan berjalan baik apabila sistem administrasi kependudukan diperbaiki dan proses pembagian diawasi dengan ketat untuk mencegah kebocoran.

Produk microfinance terlihat menjanjikan apabila bank berkomitmen untuk tidak menuntut agunan pada pinjaman yang berjumlah kecil, misalnya dibawah Rp 5 juta,per orang. Untuk kondisi Indonesia, hanya bank Pemerintah saja yang eligible memberikan kredit seperti ini. Lagi-lagi BRI yang aktif menyalurkan bantuan, dengan banyak catatan setelah beberapa tahun menunggak akhirnya BRI memutihkan kredit macet tersebut. Nampaknya selain sekedar bantuan, Pemerintah harus memberikan pengetahuan tentang dasar-dasar kewirausahaan agar uang pinjaman itu menjadi berkembang bukannya habis untuk konsumsi.

Pengentasan kemiskinan yang mengandalkan kiriman uang dari TKI nampaknya menarik apabila Departemen Tenaga Kerja memberikan keterampilan yang cukup pada calon TKI, misalnya kemampuan berbahasa asing. Namun dampak ikutan dari TKI juga kita dapati dari banyaknya pelecehan dan penyiksaan terhadap buruh migran Indonesia. Untuk jangka panjang nampaknya remitansi atau kiriman uang dari luar negeri bukanlah solusi bagi suatu bangsa yang berdaulat. Nampaknya Indonesia harus terus mencari formula yang tepat untuk menangani kemiskinan. Solusi-solusi yang ada masih banyak catatan dan tersedia ruang yang lebar untuk perbaikan dan tindak lanjut.

\section{Penutup}

Mempelajari kemiskinan kota akan menjadi pendasaran dalam menelaah dan memberi alternatif solusi, strategi kebijakan dan pembangunan teori yang cocok untuk 
pengentasan kemiskinan di kota-kota besar Indonesia, terutama Jakarta. Dalam pengamatan penulis, Pemerintah Daerah nyaris tidak memberi perhatian terhadap kemiskinan kota.

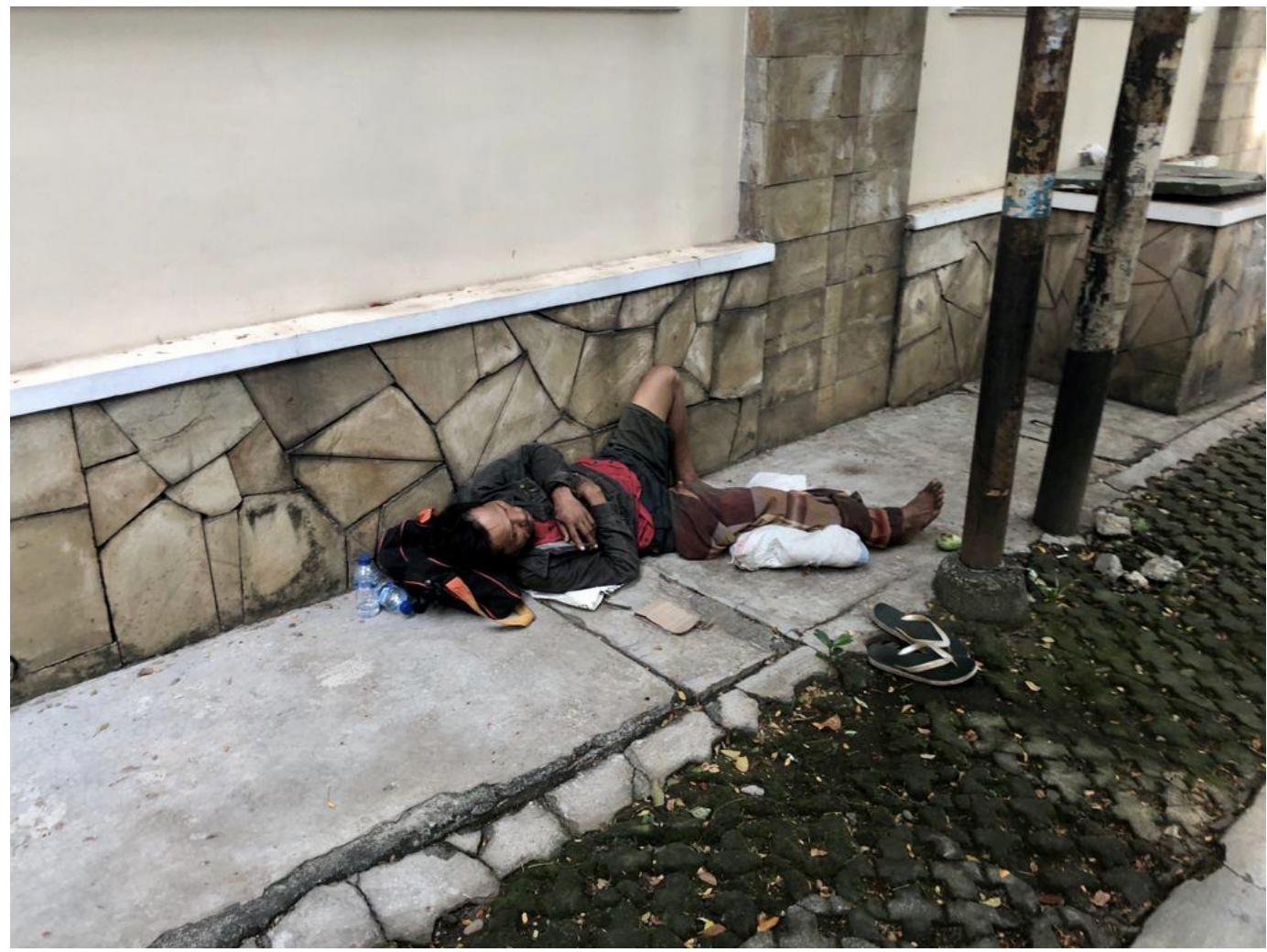

Gambar 7 - Orang Miskin di Tebet: Tidur di Trotoar.

Kita mengetahui bahwa sebagian besar dari orang-orang yang datang ke kota untuk mencari pekerjaan, karena belum adanya kebutuhan musiman menggarap sawah di desa asal. Sebagian lagi karena pekerjaan-perkerjaan yang dibutuhkan penduduk perumahan, seperti mengangkut sampah dan membersihkan gorong-gorong. Artinya jasa mereka dibutuhkan oleh penduduk kota, untuk pekerjaan-pekerjaan kelas rendah dan non higienis. Namun tidak ada sarana di mana mereka tinggal, sehingga yang terjadi adalah mereka mengambil ruang publik untuk hidup (taman, trotoar, tempat sampah, dan lahan kosong). Demikian pula mereka tidak mempunyai sumber air bersih untuk mandi dan mencuci. Dengan itu dibutuhkan suatu solusi yang lebih sistemik dan holistik untuk mengatasi kemiskinan kota. 


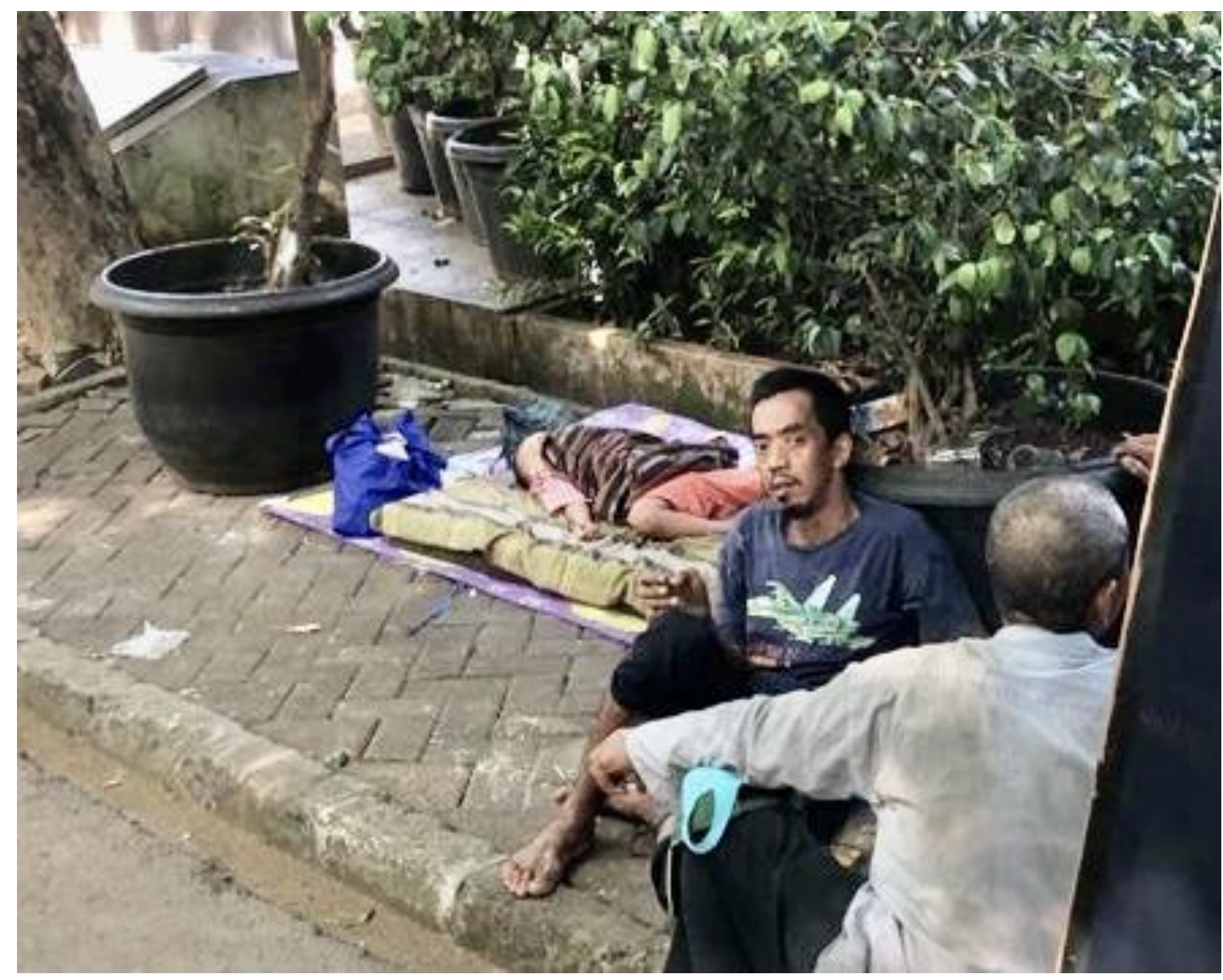

Gambar 8 - Suatu Keluarga dengan Bayi Tidur di Trotoar.

Pendalaman tema kemiskinan kota membutuhkan data kuantitatif tentang pola dan jumlah pendapatan, dana yang disiapkan oleh Pemerintah Daerah dan subsidi yang diberikan warga untuk menghidupi mereka. Belum lagi data kualitatif yang berupa asalusul kaum miskin urban, motivasi, tingkat kenyamanan dan apa yang dirasakan ketika mereka menjadi penduduk miskin perkotaan. Suatu upaya studi yang menantang dan perlu strategi seksama untuk menyelesaikannya. Sebelum akhirnya muncul dengan usulan strategis dalam memecahkan masalah kemiskinan di perkotaan Indonesia. 


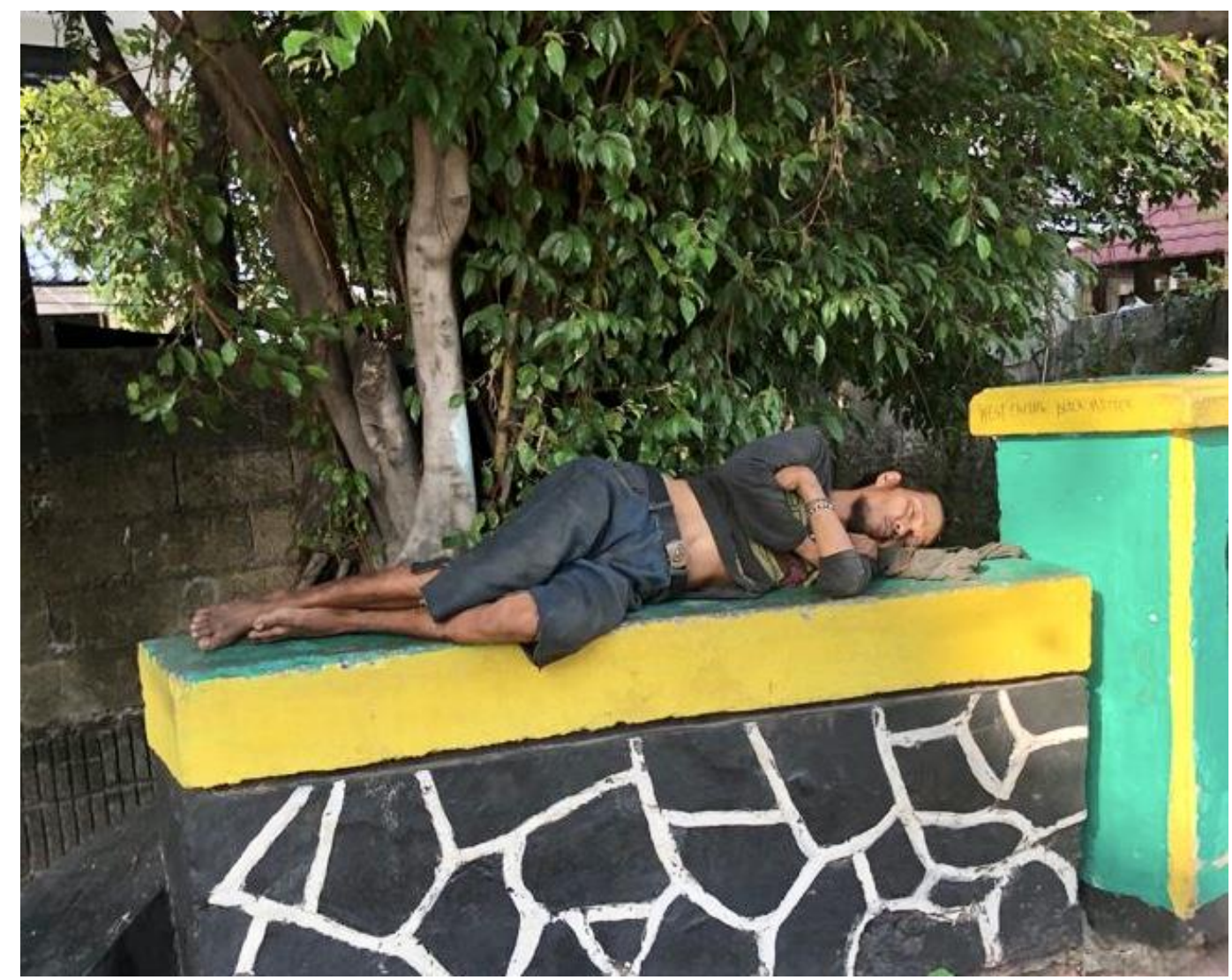

Gambar 9 - Tidur Dengan Nyaman di Teras Jembatan.

\section{Referensi}

[1] Abdullahi, Idris Isyaku, dkk. (2016). Does Poverty Influence Prevalence of Child Labor in Developing Countries? International Journal of Economics and Financial Issues. Vol. 6, Issue 1.

[2] Addae-Korankye, Alex (Oktober 2012). Microfinance: a tool for poverty reduction in developing countries. Journal of Bussiness and Retail Management Research (JBRMR). Vol 7, Issue 1.

[3] Alkire, Sabina dan Roche, Jose Manuel (Desember 2011). Sub-national Disparities and Inter-temporal Evolution of Multidimensional Poverty across Developing Countries. Oxford Poverty and Human Development Initiative (OPHI), University of Oxford.

[4] Arndt, Channing, Mahrt, Kristi dan Tarp, Finn (2017). Absolute Poverty Lines. Dalam "Measuring Poverty \& Wellbeing in Developing Countries". United Kingdom: Oxford University Press.

[5] Bargain, Olivier dan Aminjonov, Ulugbek (Mei 2020). Between a Rock and a Hard Place: Poverty and COVID-19 in Developing Countries. IZA - Institute of Labour Economy. www.iza-org. 
[6] de Haan, Arjan dan Maxwell, Simon (October 2017). Poverty and Social Exclusion in North and South. IDS Bulletin, Vol. 48 No. 1A.

[7] Díaz, Alayde Serruto dan Monagas, Maria del Cristo (13 Oktober 2017). Agricultural Policies and Their Impact on Poverty Reduction in Developing Countries: Lessons Learned from Three Water Basins in Cape Verde Serafin Corral. Sustainability 2017, 9, 1841; doi:10.3390/su9101841, www.mdpi.com/journal/sustainability.

[8] Dormekpor, Evelyn (2015). Poverty and Gender Inequality in Developing Countries. Developing Country Studies, ISSN 2225-0565, Vol.5, No.10, www.iiste.org.

[9] Elhadary, Yasin Abdalla Eltayeb (1 Maret 2012). Political Economy and Urban Poverty in the Developing Countries: Lessons Learned from Sudan and Malaysia. Journal of Geography and Geology. Vol. 4, No. 1, www.ccsenet.org/jgg.

[10] Fosu, Agustin Kwasi (2016). Growth, Inequality, and Poverty Reduction in Developing Countries: Recent Global Evidence. Research in Economic, 71.

[11] Guiga, Housseima dan Ben Rejeb, Jaleleddine (2012). Poverty, Growth and Inequality in Developing Countries. International Journal of Economics and Financial, Issues Vol. 2, No. 4, ISSN: 2146-4138, www.econjournals.co.

[12] Hanna, Rema dan Olken, Benjamin A. (2018). Universal Basic Incomes versus Targeted Transfers: Anti-Poverty Programs in Developing Countries. Journal of Economic Perspectives, Volume 32 No. 4.

[13] Husein, Zekarias, Hertel, Thomas dan Golub, Alla (2013). Climate Change Mitigation Policies and Poverty in Developing Countries. Environmental Research Letters.

Volume 8. IOP Publishing.

[14] Imai, Katsushi S., dan Cheng, Wenya (18 Agustus 2016). Dynamic and Long Term Linkages among Agricultural and Non-Agricultural Growth, Inequality and Poverty in Developing Countries. Research Institute foe Economics and Bussiness Adminisration, Kobe University.

[15] Jonaidi, Arius (April 2012). Analisis Pertumbuhan Ekonomi dan Kemiskinan di Indonesia. Jurnal Kajian Ekonomi. Volume 1, Nomor 1.

[16] Kpodar, Kangni dan Singh, Raju Jan (Desember 2011). Does Financial Structure Matter for Poverty? Evidence from Developing Countries. The World Bank, Poverty Reduction and Economic Management Unit.

[17] Olajide, Fadun S. (May 2014). Financial Inclusion, Tool for Poverty Alleviation and Income Redistribution in Developing Countries: Evidences from Nigeria. Academic Research International, Vol. 5(3).

[18] Serinoa, Moises Neil V. dan Kim Donghun (December 2011). How Do International Remittances Affect Poverty in Developing Countries? a Quantile Regression Analysis. Journal of Economic Development, Volume 36, No. 4.

[19] Siddique, Hafiz Muhammad Abubakar, dkk. (2016). Do International Migration and Remittances Reduce Poverty in Developing Countries? MPRA, Maret-April. 
[20] Sumner, Andy, Ortiz-Juarez, Eduardo dan Hoy, Chris (Juni 2020). Precarity and the Pandemic: COVID-19 and Poverty Incidence, Intensity, and Severity in Developing Countries. UNU-WIDER, Econstor, www.econstor.eu.

[21] Ucal, Meltem Şengün (2014). Panel Data Analysis of Foreign Direct Investment and Poverty from the Perspective of Developing Countries. Procedia-Social and Behaviour Sciences.

[22] Vijayakumar, Sinnathurai (Juni 2013). An Empirical Study on the Nexus of Poverty, GDP Growth, Dependency Ratio and Employment in Developing Countries. Journal of Competitiveness. Vol 5, Issue 2.

[23] Wieser, Christina (November 2011). Determinants of the Growth Elasticity of Poverty Reduction: Why the Impact on Poverty Reduction is Large in Some Developing Countries and Small in Others. WIFO dan WU-Wien, Econstor, www.econstor.eu.

[24] Yoshino, Naoyuki, Taghizadeh-Hesary, Farhad, dan Otsuka, Miyu (2017). International Remittances and Poverty Reduction: Evidence from Asian Developing Countries. ADB Institute.

[25] Zahonogo, Pam (2017). Financial Development and Poverty in Developing Countries: Evidence from Sub-Saharan Africa. International Journal of Economics and Finance; Vol. 9, No. 1. 